\title{
ANALYSIS OF MATHEMATICS LEARNING AT SMA NEGERI 2 MASOHI
}

\author{
Yosep Tetelepta ${ }^{1}$, Tanwey Gerson Ratumanan ${ }^{2}$, Christin M. Laamena ${ }^{3}$ \\ ${ }^{1}$ Guru SMA Negeri 1 Masohi \\ ${ }^{2,3}$ Dosen Program S2 Pendidikan Matematika Universitas Pattimura \\ e-mail: teteleptayosep@yahoo.com¹,gratumanan@yahoo.com², christinmath18@gmail.com³
}

\begin{abstract}
This study aims to analyze the ability of math teachers in learning plan, implementation of learning, and assessment of the learning process in the implementation of the 2013 curriculum. The research was conducted at SMA Negeri 2 Masohi, involving 5 math teachers, namely the first teacher (G1), the second teacher (G2), the third teacher (G3), the fourth teacher (G4), and the fifth teacher (G5). The data was collected by using an assessment of (1) the lesson implementation plan was prepared by each teacher, (2) the learning process was carried out by the five mathematics teachers, and (3) teachers in the assessment process and the learning outcomes of the students. The instruments consist of 3 (three) assessment formats, namely: (1) RPP assessment format, (2) learning assessment format, and (3) learning result assessment format of learners using assessment scale $0-4$. The results of the study are as follows: (1) The average RPP assessment of the five teachers is 74.40 and fall into the good category (B), (2) The average learning ability score of the five teachers is 80.00 in the good category (B), and (3) The average ability score of the five teachers in carrying out the assessment of the learners' learning outcomes is 80.71 and fall into the good category (B).
\end{abstract}

Keywords: curriculum 2013, Mathematics learning

\section{Introduction}

Nowdays, school education faced relatively big challenges. The development of science and technology, as well as the demands of relatively rapid development needs present new competency demands that must be owned by formal education graduates, including education units. Currently, the education unit is also required to produce graduates who master various fields of science as the foundation for self-development, have life skills, have learning and innovation skills, and master information and communication technology. Comprehensive competencies, covering the dimensions of social attitudes, spiritual attitudes, knowledge and skills must be formed through the educational process in the educational unit.

Permendikbud No. 54 of 2013, states that graduate qualifications that include the attitudes, knowledge, and skills of learners must be fullfill or achieved from an educational unit at every level of primary and secondary education. Learners are required to always be sustainable in learning that begins with improving the knowledge process, followed by the skills of presenting a problem and solving it, and at the end can form a good attitude in the learner.

In this context, the changes in school curriculum in Indonesia are carried out to conform the demands of this changes. The implementation of curriculum 2013 is expected to produce productive, creative, innovative, effective Indonesian people through the strengthening of integrated attitudes, skills and knowledge. The achievement of these expectations are largely determined by various factors, including learning factors. According to Permendikbud No. 81A of 2013, learning activities are an educational process that provides opportunities for learners to develop their potential into abilities that are increasingly in attitudes, knowledge, and skills needed to live and to socialize, nation, and contribute to the welfare of human life. Learning activities are directed to empower all

Received December $10^{\text {th }} 2020$, Revision January $18^{\text {th }} 2021$, Accepted for publication February $24^{\text {th }} 2021$. Copyright (C) 2021 Published by FKIP - Unpatti, ISSN 2721-3110 
potential learners into expected competencies. Therefore, learning activities must be designed and prepared as well as possible so that in the process it can run well.

Learning planning is an important aspect that teachers need to pay attention to, including math teachers. Good mathematical learning planning will enable the learning process to take place effectively, and deliver results as expected. According to Ratumanan and Rosmiati (2019), learning planning has a big role in the implementation of learning. Learning without reference to good planning is very likely to be unstructured and unable to achieve learning objectives. The existence of learning planning will provide clear direction and stages for educators in carrying out learning.

In the planning and implementation of mathematics learning today there are still many weaknesses. In learning planning, many cases of copy paste are found; there is also an RPP that is compiled together at the Committee of Teacher Deliberation (MGMP), but the teacher does not adjust the RPP to the school conditions.

In terms of Learning implementation, there are still found some learning stages that are not in accordance with RPP, less of learning involves learners in the learning process, less involves high-level thought processes/HOTS, limited utilies of learning media, etc. Ratumanan and Tetelepta (2019) describe some weaknesses of mathematics learning, such as (1) there is still a tendency of teachers to transfer knowledge, (2) Teachers have not been able to facilitate students properly in observing activities, (3) The ability of teachers to lure or motivate students to ask questions is still low; students are silent, less active in asking questions or in expressing opinions, and (4) Reasoning activities (associating) do not take place properly, teachers are less able to facilitate students in such activities.

In the implementation of curriculum 2013, the weaknesses of planning and implementation of learning as described above are expected to be minimized. In that regard, efforts to review the implementation of mathematics learning need to be done to obtain adequate information in order to improve learning planning and implementation of learning.

This research is focused on analyzing the mathematics learning process at SMA Negeri 2 Masohi. It is expected that through this research will be identifiable problems related to the planning and implementation of mathematics learning. This information is important to further find solutions in order to improve the quality of mathematics learning.

\section{Methodology}

This research is included in descriptive research with the aim of describing the ability of math teachers in planning learning and implementing the process of teaching mathematics. The subject of this study consisted of 5 (five) mathematics teachers at SMA Negeri 2 Masohi, Central Maluku Regency. The five teachers were given G1 (first teacher), G2 (second teacher), G3 (third teacher), G4 (fourth teacher), and G5 (fifth teacher).

The data collected is in the form of a learning planning plan (RPP) prepared by the five teachers and the implementation of learning in the classroom. The RPP document and learning process are then assessed using the assessment format developed by Ratumanan and Rosmiati (2019).

The data collected was then analyzed using a five-scale conversion reference in the benchmark reference assessment approach (Ratumanan \& Laurens, 2015), as follows:

Table 1. Rpp Quality Category, Learning Implementation, and Assessment Process

\begin{tabular}{ccc}
\hline Value Interval & Letter & Category \\
\hline $85 \% \leq x$ & A & Very High \\
$70 \% \leq x<85 \%$ & B & High \\
$55 \% \leq x<70 \%$ & C & Medium
\end{tabular}

Received December $10^{\text {th }} 2020$, Revision January $18^{\text {th }} 2021$, Accepted for publication February $24^{\text {th }} 2021$. Copyright (C) 2021 Published by FKIP - Unpatti, ISSN 2721-3110 


$$
\begin{aligned}
& 40 \% \leq x<55 \% \quad \text { D } \quad \text { Low } \\
& x<40 \% \quad \text { E } \quad \text { Very Low }
\end{aligned}
$$

\section{Results and Discussions}

\section{Learning Planning}

The five teachers prepared a Lesson plan (RPP) referring to the format according to the Process Standard in Permendikbud No. 22 of 2016. The RPP contains components (1) Main competencies / KI, (2) basic competencies / KD, (3) indicators of learning achievement, (4) learning objectives, (5) learning materials, (6) models / approaches / learning methods, (7) tools / media / learning resources, (8) learning steps, and (9) assessment of learning outcomes. Scoring in this lesson plan use a form developed by Ratumanan and Rosmiati (2019).

The learning planning score and implementation of mathematics learning were further analyzed using a five-scale conversion reference in the benchmark reference assessment approach by Ratumanan and Laurens (2015). The assessment results for the Lesson plan (RPP) made by the five teachers are presented in the following table:

\begin{tabular}{|c|c|c|c|c|c|c|c|c|}
\hline \multirow{2}{*}{ No } & \multirow{2}{*}{ Component of RPP } & \multicolumn{5}{|c|}{ Score RPP } & \multirow{2}{*}{ Average } & \multirow{2}{*}{ Category } \\
\hline & & G1 & G2 & G3 & G4 & G5 & & \\
\hline 1 & Competency Formulation & 75.00 & 75.00 & 75.00 & 75.00 & 81.25 & 76.25 & B \\
\hline 2 & Learning Materials & 66.67 & 66.67 & 75.00 & 66.67 & 66.67 & 68.33 & $\mathrm{C}$ \\
\hline 3 & $\begin{array}{l}\text { Media and Learning } \\
\text { Resources }\end{array}$ & 60.00 & 65.00 & 85.00 & 65.00 & 65.00 & 68.00 & $\mathrm{C}$ \\
\hline 4 & Learning Plans & 75.00 & 77.78 & 77.78 & 80.56 & 80.56 & 78.34 & B \\
\hline 5 & Assessment Plan & 58.33 & 66.67 & 83.33 & 66.67 & 66.67 & 68.33 & $\mathrm{C}$ \\
\hline & Final Score & 70.00 & 73.00 & 80.00 & 74.00 & 75.00 & 74.40 & B \\
\hline & Category & B & B & B & B & B & B & \\
\hline
\end{tabular}

Table 2. Assessment Results of Learning Implementation Plan

Table 2 shows that each teacher's RPP score is in a good category (B), except G1 which has sufficient category (C). The average RPP quality score of the five teachers is 74.40 and require into the good category (B). From five components analyzed, it appears that the competency formulation and learning plan get into the excellent category (B), learning materials, learning media, and assessment plans get into the sufficient category (C). Analysis of the components is as follows:

\section{Competency Formulation.}

In this section, the aspects observed are the accuracy of competency formulation, the alignment of indicator formulation with basic competencies, the appropriate use of operational verbs with basic competencies, and the conformity of the formulation of learning objectives with basic competencies. All teachers formulate competencies with a good category (B) with an average score of 76.25.

In the RPP compiled by G1, G2, G3, G4, G5 there are some non-operational verbs both in knowledge and in skills, including "mastering" and understanding". Indicator formulations also pay less attention to high-level thinking abilities. The verb used only gets to the $\mathrm{C} 3$ level.

\section{Learning Materials}

In this component, only G3 obtained a good category, while the other four teachers, namely G1, G2, G4, G5 obtained a sufficient category (C). The disadvantages of RPP 
are mainly related to the incomplete elaboration of the material. In RPP there is no description of the material to be discussed, so it can not be assessed about the accuracy of material organizing and the scope of learning materials, only G3 attaches the material.

\section{Media and Learning Resources}

In this component, the aspects assessed are the suitability of media and learning resources with learning objectives, the suitability of media and learning resources with the characteristics of learners, the suitability of learning media and resources with learning materials, teaching materials (LKPD, handouts, and so on), and the use of information and communication technology in supporting learning activities. For these components, G1, G2, G4, and G5 fall into the moderate or sufficient (C) category, while the G3 comes in well (B).

Weaknesses in the media component and learning resources, is as followed:

a. RPP in G1, G2, G4, G5 is not equipped with teaching materials, such as LKPD, hand out and so only G3 has teaching materials.

b. At RPP G1, described as "learners are asked to discuss with the group by paying attention to images or photos to show which domain, kodomain and range", but the teacher does not provide teaching materials that can be used as a reference or introduction to group discussions.

c. In RRP G2, G4, and G5, students are asked to observe, discuss in groups by paying attention to images or photos and working according to their respective materials, but teachers do not provide teaching materials as a benchmark for learners to discuss in groups.

\section{Learning plan}

In this component, the aspects assessed are the accuracy and clarity of the initial learning activities, the accuracy and clarity of the learning process, the suitability of learning activities with scientific approaches, accuracy and clarity of closing activities, learning activities considering the different characteristics of learners, encouraging the activeness of learners in the learning process, accommodating the development of highlevel thinking skills, and integrating local content or aspects. This component fall into the category of good (B) for G1, G2, G3, G4, and G5.

In the RPP of the five teachers there are several shortcomings related to this component, they are unseen (1) Differences in student characteristics, (2) Development of high order thinking skills of learners, and (3) aspects of local content. These means that in the development of RPP, there has not been done analysis of student characteristics, analysis of learning materials, and analysis of learning models. But seen in detail the learning steps in the RPP are described in a structured and clear. The learning process in the introduction activities, main activities, and closing activities are well written. In the Main activities of learning, scientific approaches are already seen in the learning steps.

\section{Assessment Plan}

In this component the aspects assessed are the suitability of the form, technique, and instrument assessment and indicators, the assessment plan involves the cognitive, affective, and psychomotor realms, and the completeness of the assessment instrument (reference assessment, question and key Answers). Deficiencies in RPP compiled by teachers G1, G2, G4, G5 were found in the "assessment plan" component, and had an average score of 68.33 and fall into the sufficient category (C). G3 get into the good category (B).

The weeknesses of RPP related to the components of the assessment plan, are as follows:

a. G1, G2, G4, G5 have not compiled knowledge assessment instruments, only G3 is well composed.

Received December $10^{\text {th }} 2020$, Revision January $18^{\text {th }} 2021$, Accepted for publication February $24^{\text {th }} 2021$.

Copyright (C) 2021 Published by FKIP - Unpatti, ISSN 2721-3110 
b. G1, G2, G4, G5 do not attach scoring guidelines or assessment rubrics while G3 properly attaches them.

G1 writes assessments on RPP, for knowledge assessment using written tests, on attitude assessments using self-assessment, and on skill assessment using performance assessments, but there are no instruments are prepared yet to measure such assessments. Assessments for G2, G4, G5 on knowledge assessment are listed using written tests but have not attached questions to the assessment, while attitude and skill assessments have instruments to measure them. For G3, in the assessment of knowledge using written tests and there are instruments of knowledge assessment and scoring, the thing for attitude assessment, while for skill assessment is not attached because at this meeting is not in the value of skill assessment.

From the results of the interview G1, G2, G4, G5 does not attach the instrument of knowledge assessment because it is still in the process of completion, but when asked to show it G1, G2, G4, G5 can not show the attachments of the assessment. From the results of the interview, it can also be identified that the five teachers have been able to make RPP independently, although not optimally.

\section{Learning Implementation Process}

Assessment of the learning process is carried out when the teacher manages the learning. The assessment was carried out using the assessment format developed by Ratumanan and Rosmiati (2019). The assessment results are presented in the following table.

Table 3. Assessment of Learning Implementation

\begin{tabular}{|c|c|c|c|c|c|c|c|c|}
\hline \multirow{2}{*}{ No } & \multirow{2}{*}{ Learning Component } & \multicolumn{5}{|c|}{ Score } & \multirow{2}{*}{ Average } & \multirow{2}{*}{ Category } \\
\hline & & G1 & G2 & G3 & G4 & G5 & & \\
\hline 1 & Preliminary Activities & 81.25 & 81.25 & 81.25 & 81.25 & 87.50 & 82.50 & $\mathrm{~B}$ \\
\hline 2 & Materials Presentation & 81.25 & 75.00 & 87.50 & 81.25 & 81.25 & 81.25 & B \\
\hline 3 & Learning Implementation & 75.00 & 79.17 & 79.17 & 79.17 & 79.17 & 78.34 & B \\
\hline 4 & $\begin{array}{l}\text { Use of media/ learning } \\
\text { resources }\end{array}$ & 75.00 & 62.50 & 75.00 & 75.00 & 75.00 & 72.50 & B \\
\hline 5 & $\begin{array}{l}\text { Personality and ability to } \\
\text { interact }\end{array}$ & 79.17 & 83.33 & 83.33 & 79.17 & 83.33 & 81.67 & $\mathrm{~B}$ \\
\hline 6 & Learning closing ability & 75.00 & 87.50 & 87.50 & 87.50 & 87.50 & 85.00 & $\mathrm{~A}$ \\
\hline & Final score & 78.13 & 79.17 & 82.29 & 80.21 & 81.25 & 80.00 & $\mathrm{~B}$ \\
\hline & Category & B & $\mathrm{B}$ & $\mathrm{B}$ & B & $\mathrm{B}$ & B & \\
\hline
\end{tabular}

Assessment results in Table 3. demonstrate the ability of the five teachers (G1, G2, G3, G4, G5) in carrying out learning into a good category (B). The average score obtained by the five teachers is 80.00 so it fall into the good category (B). The analysis of each component is as follows:

\section{Preliminary Activities.}

In this component the aspects assessed are class organizing, linking the material to be studied with the experience of learners or with previous material, and conveying the benefits of learning materials and / or providing motivation. The average score obtained in the "preliminary activity" component is 82.50 , and is in the good category (B). The ability of the five teachers (G1, G2, G3, G4, G5) in opening learning, organizing classes, motivating learners and conveying the benefits of the material to be studied is good. The

Received December $10^{\text {th }} 2020$, Revision January $18^{\text {th }} 2021$, Accepted for publication February $24^{\text {th }} 2021$. Copyright (C) 2021 Published by FKIP - Unpatti, ISSN 2721-3110 
five teachers have started by providing motivation and have been able to show the benefits of learning materials.

\section{Learning implementation process}

In this component, the aspects assessed are the teacher's ability to present the material clearly, structured, and easy to understand, mastery of the class, directing learners to observe, encouraging learners to ask questions, directing learners to gather information (trying), directing learners to analyze or reason (associate), and facilitate learners to communicate the results of work, as well as in the use of media and learning resources.

The average score in material presentation is 81.25 and get into the good category (B). Although the five teachers have mastered the presentation of the material well and fall into a good category, but the ability to present the material has not been entirely good because the teacher's preparation is not maximal yet. The weaknesses that can be identified in learning are as follows:

a. The link of the material with contextual aspects still does not look well.

b. Enrichment of materials and high order thinking process is still not noticed by teachers.

In giving math questions to students, teachers are still focused on the aspects of understanding (C2) and application (C3). Teachers should pay attention to the development of critical thinking skills and high-level thinking.

In mathematics learning, the five teachers applied a scientific approach well, with the average score obtained was 78.34. In the RPP, the five teachers listed using the approach/model directed in the 2013 curriculum. G1, G2, G5 use problem-based discovery learning models with scientific approaches; G3 uses a cooperative learning model (Think Pair and Share) with a scientific approach; G4 uses the Q\&amp;A, interview, and discussion methods. The process of knowledge activities by learners or groups of learners has not been fully observed. However, there are some shortcomings in the learning process that can be identified, namely:

a. The tendency of teachers to transfer knowledge is still apparent. Rpp compiled by the five teachers, all teachers write down or list the core activities starting with dividing the learners into groups, then each group discusses for each given material. However, in the learning process, in the core activities, G1, G2, and G5 directly explain the material accompanied by several examples, then provide opportunities for learners to read and relearn the materials and practice questions and provide exercises for learners to do.

b. The process of observing in class has not been fully facilitated by the teacher properly. In this process, teachers must be creative in making teaching materials, presentation slides or visual materials such as videos, images and so on. From the observations of the five teachers, there has not been any interesting material or teaching materials to encourage the observation process to take place properly. Teachers only use package books without using LCD in learning.

c. The process of stimulating or motivating learners in asking questions by teachers is still not good. The students only pay attention to the teacher's explanation, are less active in expressing opinions or asking questions.

d. The reasoning/ thinking process (associating) has not been going well, teachers are less able to direct students in the activity.

In the media usage and learning resources section, the five teachers scored well (B), with the average score for the "ability to use learning media" component being 72.50 . The main drawback that can be identified is that teachers do not involve the use of communication and information technology in the teaching and learning process. The use of communication technology and information is important in developing data literacy and digital literacy. Here teachers have not used or managed the learning process by using communication and information technology, for example using mathematical software,

Received December $10^{\text {th }} 2020$, Revision January $18^{\text {th }} 2021$, Accepted for publication February $24^{\text {th }} 2021$. Copyright (C) 2021 Published by FKIP - Unpatti, ISSN 2721-3110 
utilizing the internet, using LCD projectors, and so on, because it is constrained by existing facilities in schools.

The connection formed between teachers and learners is relatively good. There are no students who are disturbed or uncomfortable in the learning process. The five teachers in the learning process or group discussion process, always facilitate the learners well, if the learners do not understand or have difficulty in solving the questions given, the teacher is always there to accompany. The five teachers were also able to master the class well. The average score for personality components and ability to interact is 81.67 or get into the good category (B).

\section{Closing Activities}

In this component, the aspect assessed is to reflect or make a summary by involving learners and carry out follow-up in the form of direction, strengthening, or task as part of remedial / enrichment. All teachers in closing the learning process already have excellent skills. In this activity, teachers direct students to reflect or make a summary of the material that has been studied. The five teachers have also carried out follow-up evaluations of learning, such as providing direction, strengthening, assessment, and also tasks to do at home. This has been seen in the learning process carried out by the five teachers.

From interviews conducted with the five teachers about the teaching and learning process in the classroom, it can be concluded that in the 2013 curriculum learning process there are several obstacles, such as, time constraints that makes sometimes do not do the assessment at the end of learning and then during the learning process the learners are less active so that the learning does not go well.

The results of research on teachers' ability in the implementation of the above learning are also relevant to the findings of Ratumanan (2014), that there are some weaknesses that are still find in the learning management in the implementation of the 2013 curriculum, They are:

a. Class organizing, especially in setting the sitting position of learners while working in groups still gets less attention from teachers. In three teaching and learning activities, students are organized into small groups, but the sitting position is not regulated by the teacher. As a result group activities do not develop optimally.

b. In general, the learning steps have shown the use of scientific approaches. But it seems that the creativity of teachers in designing learning is still limited. Observing activities for example are more dominated by reading the material in the textbook (or its copy).

c. The tendency to dominate learning is still evident in the teachers observed. Teachers seemed less patient waiting for the results of the students' work.

d. The use of media in learning is still less noticed by teachers.

There is a tendency for teacher problems related to material mastery. This can be seen from the example given by the teacher or the questions assigned to be done by students relatively measuring low level of thinking ability. Enrichment and problem solving forms in the books of learners with relatively higher levels of difficulty tend to be avoided by teachers.

\section{Conclusion}

Based on the results and discussions described above, it can be concluded that:

1) Planning of mathematics learning in the implementation of curriculum 2013 at SMA Negeri 2 Masohi is in a good category (B). This is indicated by obtaining an average value of 74.40. This means that teachers are already able to make RPP even though there are things that need to be fixed. RPP components that must be improved are in the components of learning materials, media and learning resources, and assessment plans that are in sufficient categories (C).

Received December $10^{\text {th }} 2020$, Revision January $18^{\text {th }} 2021$, Accepted for publication February $24^{\text {th }} 2021$. Copyright (C) 2021 Published by FKIP - Unpatti, ISSN 2721-3110 
2) The process of implementing mathematics learning in the implementation of the 2013 curriculum at SMA Negeri 2 Masohi is in a good category (B). This is indicated by obtaining an average value of 80.00 . This means that teachers are able to carry out the learning process in the classroom well but there are things that need to be improved. In RPP, the learning model is centered on students centered learning with a scientific approach, but in the implementation of learning, there is still a tendency of teachers to dominate learning with knowledge transfer.

\section{REFERENCES}

Adi Wahyu Kuncara1, Imam Sujadi, Riyadi. 2016. Analisis Proses Pembelajaran Matematika Berdasarkan Kurikulum 2013 pada Materi Pokok Peluang Kelas X SMA Negeri 1 Surakarta. Jurnal Pembelajaran Matematika. Vol.4, No.3. Mei 2016

Chairi Mutia Lubis, Edy Surya, dkk. 2016. Analisis Keefektifan Belajar Matematika Melalui Pendekatan Stop Think Do Pada Siswa MTs. Budi Agung. UNION: Jurnal Pendidikan Matematika Vol 4 No 2, Juli 2016

Hasan Sastra Negara, Imam Sujadi, Pangadi. 2013. Analisis Pembelajaran Matematika Pada Sekolah Yang Menerapkan Pendekatan Pmri Dan Sekolah Yang Tidak Menerapkan Pendekatan Pmri Di Kota Yogyakarta. Jurnal Pembelajaran Matematika. Vol.1, No.7, 2013

------------------. 2014. Analisis Pembelajaran Matematika Pada Sekolah Dasar Yang Menerapkan Pendekatan Pmri Dan Sekolah Dasar Yang Tidak Menerapkan Pendekatan Pmri Di Kota Yogyakarta. TERAMPIL: Jurnal Pendidikan dan Pembelajaran Dasar Volume 1 Nomor 1 Juni 2014.

Huri Suhendri, Sudiyah Anawati, Nurhayati, 2014. Analisis Pembelajaran Matematika Dengan Pendekatan Model Pembelajaran Konstruktif Berbasis Penemuan Terbimbing Di Sekolah Menengah Kejuruan (SMK) Se-Jakarta Selatan. Prosiding Seminar Nasional Pendidikan Matematika STKIP Siliwangi. Volume 2, Tahun 2014

Kusnadi, Dedi., Suradi Tahmir., \& Ilham Minggi. 2014. Implementasi Kurikulum 2013 dalam Pembelajaran Matematika di SMA Negeri 1 Makassar. MaPan, Jurnal Matematika dan Pembelajaran. Volume 2, Nomor 1, Juni 2014.

Peraturan Menteri Pendidikan dan Kebudayaan Republik Indonesia Nomor 22 Tahun 2016 tentang Standar Proses Pendidikan Dasar dan Menengah. Jakarta.

Peraturan Menteri Pendidikan dan Kebudayaan Republik Indonesia Nomor 23 Tahun 2016 tentang Standar Penilaian Pendidikan. Jakarta.

Peraturan Menteri Pendidikan dan Kebudayaan Republik Indonesia Nomor 54 Tahun 2013 tentang Standar Kompetensi Lulusan. Jakarta.

Peraturan Menteri Pendidikan dan Kebudayaan Republik Indonesia Nomor 81A Tahun 2013 tentang Implementasi Kurikulum. Jakarta.

Ratumanan, T. G. dan Imas Rosmiati. 2019. Perencanaan Pembelajaran. Depok: PT Raja Grafindo Persada.

Ratumanan, T. G. dan Yosep Tetelepta. 2019. Analisis Pembelajaran Matematika Berdasarkan Kurikulum 2013 Pada SMA Negeri 1 Masohi. JUMADIKA, Jurnal Magister Pendidikan Matematika, Volume 1 No 1, 2019.

Ratumanan, T. G dan Theresia Laurens 2015. Penilaian Hasil Belajar pada Tingkat Satuan Pendidikan. Yogyakarta: Pensil Komunika.

Ratumanan, T. G., \& Carolina S. Ayal. 2018. Problem Solving Based Learning Model Alternative Model of Developing High Order Thinking. International Journal of Health Medicine and Current Research Vol. 3, Issue 02, pp.857-865, June, 2018

Received December $10^{\text {th }} 2020$, Revision January $18^{\text {th }} 2021$, Accepted for publication February $24^{\text {th }} 2021$.

Copyright (C) 2021 Published by FKIP - Unpatti, ISSN 2721-3110 
Ratumanan, T. G. 2014. Kompetensi Guru Matematika SMA dalam Hubungannya dengan Implementasi Kurikulum 2013 di Provinsi Maluku. Makalah. Tidak dipublikasikan. Ambon

Suci Rakhmawati, Novianti Muspiroh, Nurul Azmi. 2016. Analisis Pelaksanaan Kurikulum 2013 Ditinjau Dari Standar Proses Dalam Pembelajaran Biologi Kelas X Di SMA Negeri 1 Krangkeng. Scientiae Educatia: Jurnal Sains dan Pendidikan Sains Vol. 5 No. 2, 2016.

Sumeyra Dogan Coskun, Mine Isiksal Bostan. 2018. The Analysis of a Novice Primary Teachers' Mathematical Knowledge in Teaching: Area Measurement. International Journal For Mathematics Teaching And Learning. 2018, Vol. 19.1

Tetelepta Yosep. 2020. Analisis Pembelajaran Matematika Berdasarkan Kurikulum 2013 Pada SMA Negeri 2 Masohi. Tesis. Ambon: PPs Universitas Pattimura. 